\title{
Granulocyte-Macrophage Colony-stimulating Factor Promotes Differentiation and Survival of Human Peripheral Blood Dendritic Cells In Vitro
}

\author{
Sergiusz Markowicz and Edgar G. Engleman \\ Department of Pathology, Stanford University School of Medicine, Stanford, California 94305
}

\begin{abstract}
Interest in human dendritic cells (DC) has been heightened recently by the discovery that this cell type is a primary target of the human immunodeficiency virus, the causative agent of AIDS. DC are bone marrow-derived cells with an extraordinarily potent ability to promote the immunological activity of $T$ lymphocytes. Unfortunately, since DC constitute $<0.5 \%$ of peripheral blood mononuclear cells and die within a few days of their isolation, they are not readily accessible to study. We report here that granulocyte-macrophage colony-stimulating factor (GM-CSF), a cytokine with well-recognized effects on granulocyte and macrophage maturation, profoundly affects the morphology and viability of DC isolated from peripheral blood. GM-CSF not only promotes DC survival but also induces DC differentiation to mobile, reversibly adherent cells with long-branched projections. DC cultured in GM-CSF survive for up to 6 wk and retain their ability to stimulate the proliferation of $T$ cells in allogeneic and autologous mixed leukocyte reactions. (J. Clin. Invest. 1990. 85:955-961.) autologous mixed leukocyte reaction • cytokine • Langerhans cells • macrophage $\bullet T$ lymphocyte
\end{abstract}

\section{Introduction}

Bone marrow-derived dendritic cells (DC) ${ }^{1}$ are highly efficient at presenting foreign antigen to $T$ cells, thus initiating an immune response. Such cells are distinguishable from other mononuclear cells on the basis of their morphology and surface phenotype (1-4). In peripheral blood DC appear as large $(>15 \mu \mathrm{m})$ irregularly shaped cells, but in tissues such as skin and lymphoid organs DC have multiple dendrite-like cellular projections. Although no DC-specific surface antigens have been described, DC in both blood and tissues can be readily distinguished from other leukocytes on the basis of their dense expression of class II major histocompatibility complex deter-

Address reprint request to Dr. Engleman, Stanford University Blood Center, 800 Welch Road, Palo Alto, CA 94304.

Received for publication 8 August 1989 and in revised form 9 September 1989.

1. Abbreviations used in this paper: CM, complete medium; DC, dendritic cell, GM-CSF, granulocyte-macrophage colony-stimulating factor; MLR, mixed leukocyte reaction; Tsn, T cell supernatant.

J. Clin. Invest.

(c) The American Society for Clinical Investigation, Inc.

0021-9738/90/03/0955/07 \$2.00

Volume 85, March 1990, 955-961 minants and their lack of the monocyte/macrophage-associated antigen Leu M3, the T cell antigen CD3, natural killer cell antigen CD16, and B cell antigens, CD20 and CD22. Interest in DC has grown in recent years partly as a result of studies in mice suggesting that this cell type, in contrast to macrophages, can prime naive $T$ cells to become antigen-specific $T$ helper cells or virus-specific cytotoxic cells (5-7). Moreover, recent studies in humans have demonstrated that $\mathrm{DC}$ can be infected with the human immunodeficiency virus (HIV), the causative agent of AIDS, and may serve as a major reservoir for the virus, in vivo $(8,9)$. Unfortunately, detailed studies of the functions of human DC and the effects of HIV infection on this cell type have been constrained by the fact that DC constitute $<0.5 \%$ of peripheral blood mononuclear cells and survive for only a few days in vitro.

In the current report, we show that peripheral blood DC differentiate into multibranched cells and survive, functionally intact, for prolonged periods in the presence of granulocytemacrophage colony-stimulating factor (GM-CSF), a cytokine known primarily for its effects on the maturation of granulocyte and macrophage precursors $(10,11)$. The approach used here should make it possible to undertake a broad range of studies of DC heretofore not possible.

\section{Methods}

Isolation of peripheral blood DC, monocytes, $T$ cells, and B cells Human peripheral blood DC were obtained with a previously described procedure (4) with the modifications indicated below. Briefly, mononuclear cells were isolated by Ficoll-Hypaque gradient centrifugation (12). Low-density and high-density mononuclear cells were separated in a four-step discontinuous Percoll (Pharmacia LKB, Uppsala, Sweden) gradient. $75 \%(7 \mathrm{ml}), 50.5 \%(16 \mathrm{ml}), 40 \%(4 \mathrm{ml})$, and $30 \%(3$ $\mathrm{ml})$ dilutions of stock isoosmotic solution of Percoll $(1.130 \mathrm{~g} / \mathrm{ml})$ in Dulbecco's calcium- and magnesium-free PBS containing 5\% heat-inactivated pooled human serum (DPBS/HS) were layered sequentially. $100-200 \times 10^{6}$ mononuclear cells suspended in the Dulbecco's PBS/ human serum were overlayered onto the gradient and centrifuged at $1000 \times \mathrm{g}$ for $25 \mathrm{~min}$ at $4^{\circ} \mathrm{C}$. Low-density cells, mostly monocytes, were collected from the interface over $50.5 \%$ Percoll solution (density 1.065 $\mathrm{g} / \mathrm{ml}$ ), while high-density cells were collected from the interface between $75 \%$ and $50.5 \%$ Percoll solutions. T cells forming spontaneous rosettes with sheep red blood cells were removed from the high-density cell fraction by Ficoll-Hypaque centrifugation (13). The remaining high-density non- $T$ cells (including DC) were suspended in Teflon vessels in RPMI- 1640 medium supplemented with $2 \mathrm{mM} \mathrm{L-glutamine,}$ $100 \mu \mathrm{g} / \mathrm{ml}$ streptomycin, $100 \mathrm{U} / \mathrm{ml}$ penicillin, and $10 \%$ heat-inactivated pooled human serum (hereafter designated complete medium [CM] ) and cultured at $37^{\circ}$ in $10 \% \mathrm{CO}_{2}$ in air for $2 \mathrm{~d}$. Thereafter, the cells were centrifuged over a second discontinuous Percoll gradient consisting of $75 \%(2 \mathrm{ml}), 50.5 \%(4.5 \mathrm{ml}), 40 \%(1 \mathrm{ml})$, and $30 \%(1 \mathrm{ml})$, and the DC were contained entirely within the low-density fraction. 
This fraction was further depleted of contaminating macrophages by a solid-phase absorption (panning) procedure on human IgG-coated Petri dishes (4). By cytofluorographic analysis using two-color staining with phycoerythrin and fluorescein-conjugated monoclonal antibodies, $50-70 \%$ of the recovered cells stained brightly with a monoclonal anti-HLA-DR antibody (CA141), and did not stain simultaneously with any of the following antibodies defining leukocyte subsets: Leu M3 (monocyte/macrophages), OKT3 (anti-CD3, T cells), Leu 5 (anti-CD2, T and natural killer cells), Leu 12 (anti-CD19, B cells), Leu 16 (anti-CD20, B cells), and Leu 11c (anti-CD16, natural killer cells). A final panning procedure (14) simultaneously utilizing Leu M3, OKT3, Leu 12, and Leu $11 \mathrm{c}$ antibodies yielded $>70 \%$ of cells with the above staining characteristics. Final yields of DC were $0.08-0.6 \%$ of starting mononuclear cells.

Other cell populations were obtained during the same procedure and further purified as follows: The monocyte enriched "primary" low-density fraction was refloated on Percoll and purified by panning on human IgG-coated Petri dishes. The "secondary" high-density B cell-enriched fraction was further purified by removing residual monocytes, T cells, and NK cells on Petri dishes coated with Leu M3, OKT3, and Leu $11 \mathrm{c}$ antibodies. The T cell-enriched fraction was depleted of residual monocytes by overnight adherence in plastic vessels at $37^{\circ} \mathrm{C}$. During the 2-d isolation procedure, unfractionated peripheral blood mononuclear cells were maintained at $37^{\circ} \mathrm{C}$ in Teflon vessels.

By cytofluorographic analysis $>90 \%$ of the macrophage-enriched population stained with Leu M3 antibody, $>96 \%$ stained with OKM1, whereas $\leq 2 \%$ were $\mathrm{CD} 3+$ and $\leq 1 \% \mathrm{CD} 20+.96 \%$ of this population stained with an anti-HLA-DR antibody (CA141), but the mean fluorescence was $1 \log$ lower than that found in the DC-enriched fraction. The B cell fraction contained $>60 \% \mathrm{CD} 20+$ cells, $\leq 1 \% \mathrm{CD} 3+, \leq 3 \%$ CD16+ cells, and $\leq 1 \%$ Leu M3+ cells. $>95 \%$ of the cells in the T lymphocyte-enriched fraction were $\mathrm{CD} 3+$, while $\leq 1 \%$ were either CD20+ or Leu M3+.
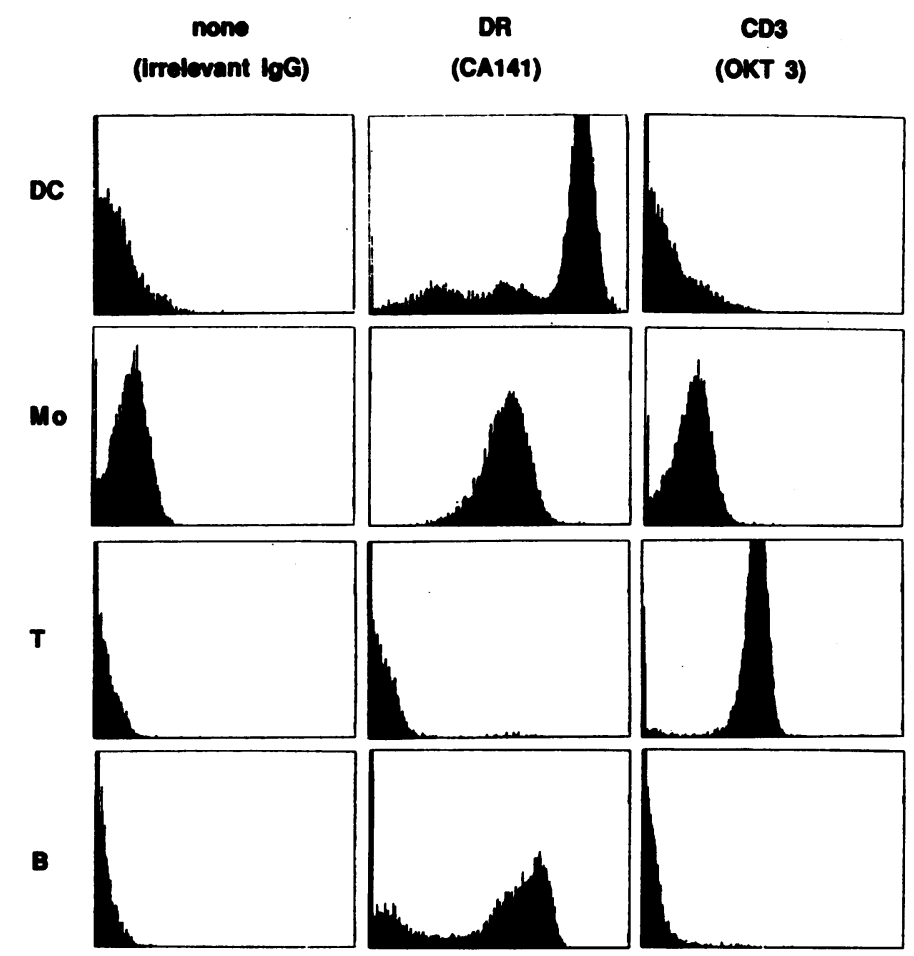

$T$ cell supernatant ( $T s n)$. Tsn was obtained from cultures of $T$ cells pulsed $18 \mathrm{~h}$ with $5 \mu \mathrm{g} / \mathrm{ml}$ PHA, washed four times, and maintained at $37^{\circ} \mathrm{C}$ for an additional $4 \mathrm{~d}$.

Mixed leukocyte reactions. (MLRs). $20 \times 10^{3}, 10 \times 10^{3}$, or $5 \times 10^{3}$ DC, monocytes, or B cells were cultured for 0 or $18 \mathrm{~d}$ in microwells containing $0.2 \mathrm{ml} \mathrm{CM}$ alone or $\mathrm{CM}$ supplemented with $100 \mathrm{U} / \mathrm{ml}$ GM-CSF. Thereafter, the microtiter plates containing these cells were irradiated (3,000 rads from a cesium- 137 source) and $50 \times 10^{3}$ cryopreserved allogeneic or autologous $\mathrm{T}$ cells were added in $\mathrm{CM}$ alone or CM supplemented with $50 \mathrm{U} / \mathrm{ml} \mathrm{GM-CSF}$ ( $0 \mathrm{~d}$ MLRs only). During the pre-MLR 18-d culture, each cell population was fed every $8 \mathrm{~d}$ with CM with or without GM-CSF. After $18 \mathrm{~d}$, half the medium was removed and $50 \times 10^{3} \mathrm{~T}$ cells in $0.1 \mathrm{ml} \mathrm{CM}$ were added. All MLRs were carried out at $37^{\circ} \mathrm{C}$ in $10 \% \mathrm{CO}_{2}$ in air. On the 6th day of culture $1 \mu \mathrm{Ci}$ per well $\left[{ }^{3} \mathrm{H}\right]$ thymidine (specific activity $6.7 \mathrm{Ci} / \mathrm{mmol}$ ) was added to the wells, and $16 \mathrm{~h}$ later the cells were harvested with a MASH apparatus (Otto Hiller Co., Madison, WI) for determination of $\left[{ }^{3} \mathrm{H}\right]$ thymidine incorporation. Results represent the mean counts per minute \pm SD of five replicate cultures.

\section{Results and Discussion}

Using a modification of a multistep procedure initially described by Young and Steinman (4), we obtained highly enriched DC from human peripheral blood. The DC in these preparations are large $(>15 \mu \mathrm{m})$ and distinguishable by flow cytometry from other mononuclear cells on the basis of their high surface density of HLA-DR and absence of detectable T, B, or monocyte markers (Fig. 1). When dispersed in culture these cells rapidly $(2-4 \mathrm{~h})$ form aggregates, remain viable for a few days in clumps, and then die. When DC isolated in this manner were exposed to supernatants (Tsn) of $\mathrm{T}$ cells which
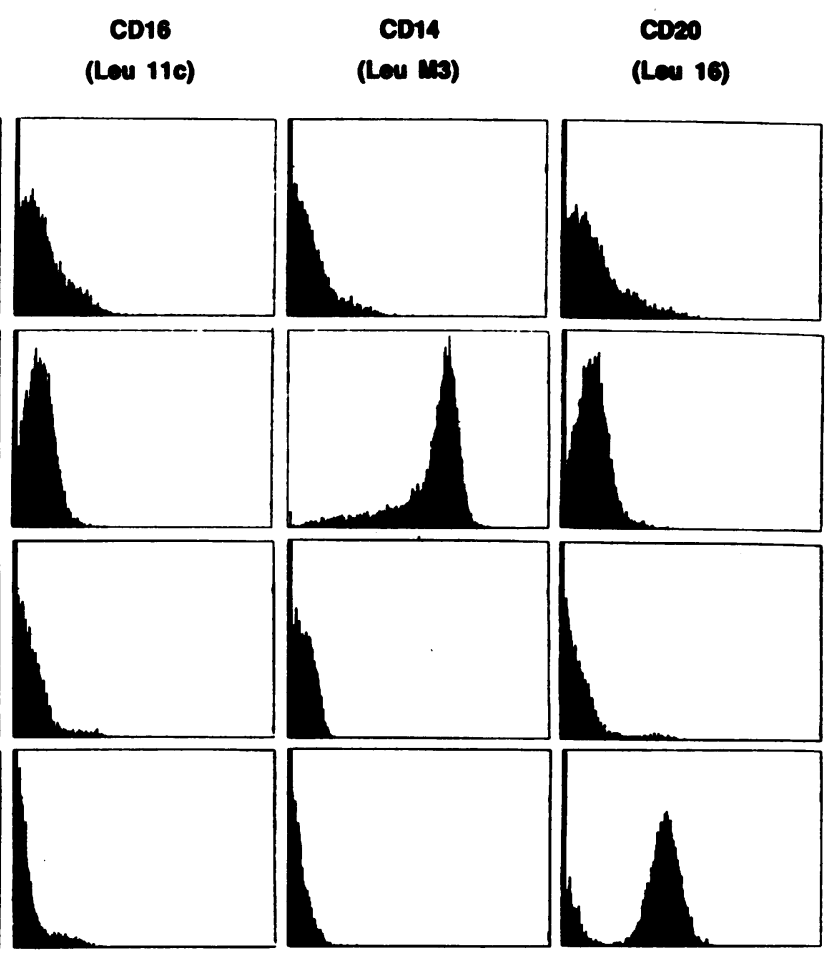

FLUORESCENCE WTENSTYY

Figure 1. Cell surface markers on freshly isolated dendritic cells $(D C)$, macrophages $(M o)$, and $T$ and B lymphocytes $(T$ and $B)$ obtained from peripheral blood. Immunofluorescence analysis was performed on an Epics Profile II (Coulter Cytometry, Epics Division, Hialeah, FL). Histograms display number of cells versus intensity of fluorescence on a logarithmic scale. Each histogram represents an analysis of 10,000 cells. 

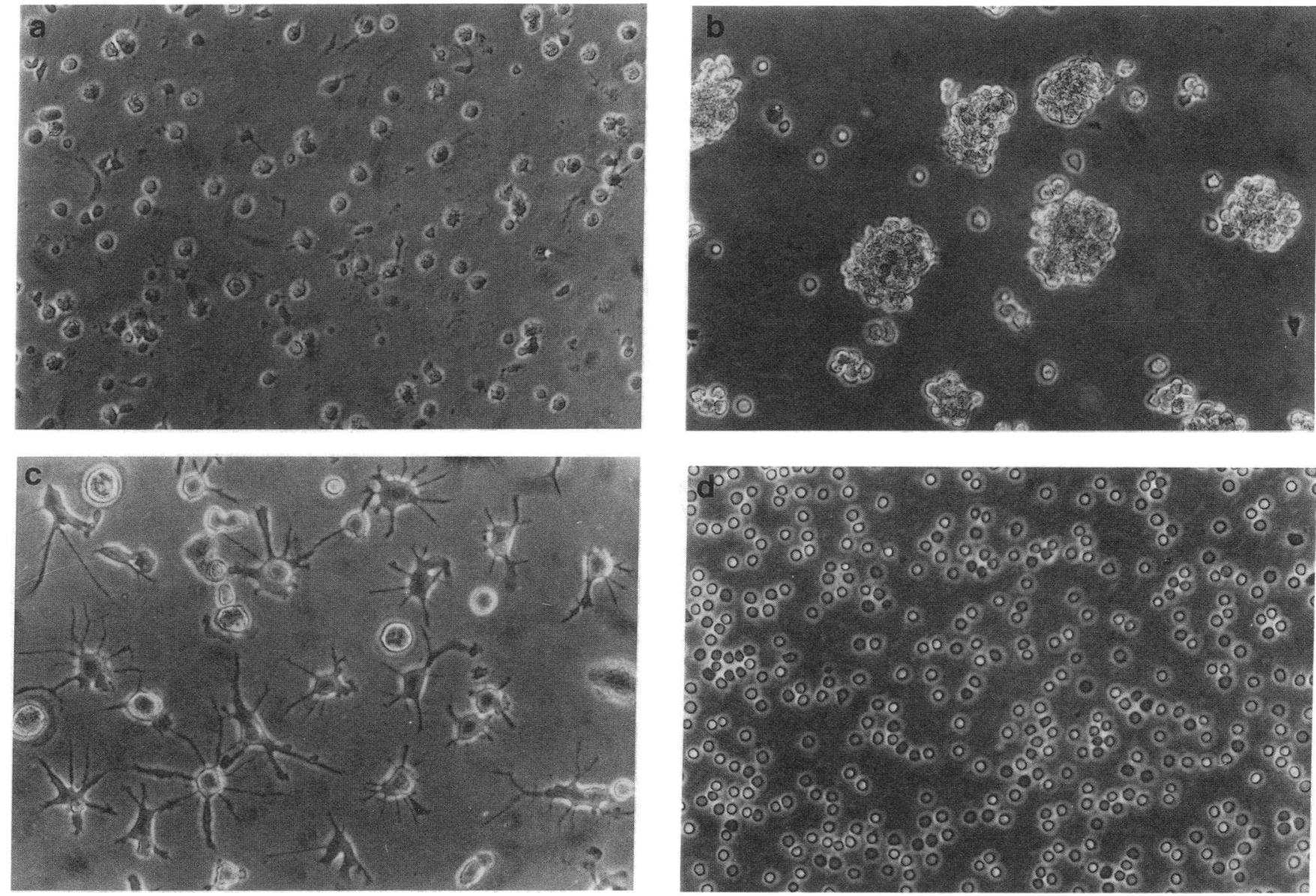

Figure 2. Morphology of human peripheral blood DC. DC were isolated from peripheral blood as described in Methods. Samples shown represent $(a)$ fresh DC suspended in serum-free medium and centrifuged immediately to avoid aggregate formation, $(b)$ DC aggregates formed within $2 \mathrm{~h}$ of culture in CM; (c) DC after culture for $21 \mathrm{~d}$ in CM supplemented with $100 \mathrm{U} / \mathrm{ml}$ native GM-CSF, and $(d)$ fresh T cells (shown for comparison). For long-term culture, DC were suspended in CM supplemented with GM-CSF in 12-well dishes (Costar Data Packaging Corp., Cambridge, MA) at a final cell concentration of $0.15 \times 10^{6} / \mathrm{ml}$. Cultures were fed every $8 \mathrm{~d}$ with fresh CM containing GM-CSF. DC maintained in Tsn were identical in appearance to those maintained in GM-CSF. All photographs were taken through an inverted phase-contrast microscope $(\times 143)$.

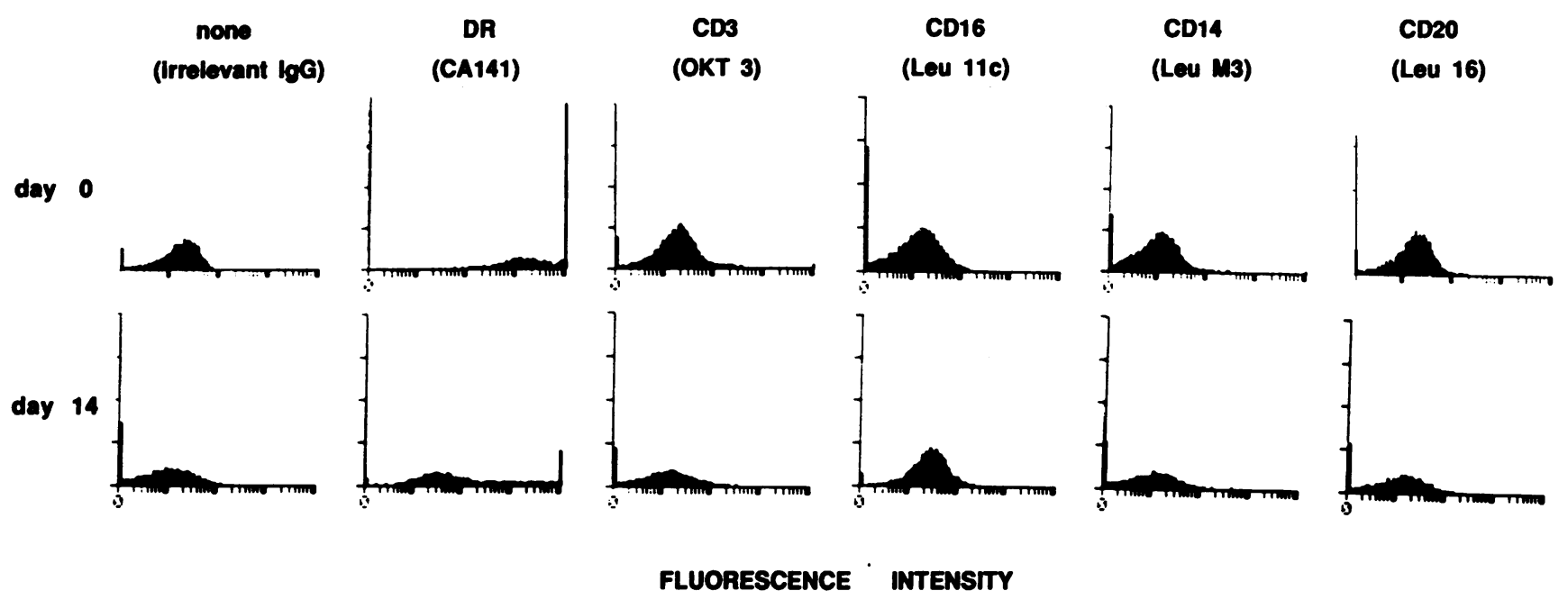

Figure 3. Comparison of cell surface markers on freshly isolated DC and DC cultured for $14 \mathrm{~d}$ in CM supplemented with $100 \mathrm{U} / \mathrm{ml} \mathrm{GM-CSF}$. Immunofluorescence was performed on a cell sorter (model $50 \mathrm{H}$, Ortho Diagnostic Systems, Inc., Raritan, NJ). Histograms display cell number versus fluorescence intensity on a logarithmic scale. Each histogram represents an analysis of $\sim 5,000$ cells. 
had been stimulated with phytohemagglutinin (PHA), the clumped cells disaggregated, differentiated into reversibly adherent cells with long-branched processes (as in Fig. 2), and remained viable for $>1$ mo in culture. The surface phenotype of DC maintained in Tsn for 2 wk was similar to that of freshly isolated DC, with widely variable staining for HLA-DR and no staining for other leukocyte markers (Fig. 3). Supernatants prepared as above from the $T$ cells of 10 consecutive subjects had identical activity.

This result suggested that one or more T cell-derived cytokines induce DC differentiation and survival in culture. When a spectrum of purified human cytokines was tested for effects on DC, GM-CSF alone recapitulated the activity of Tsn (Table I). Purified native or recombinant GM-CSF promoted DC differentiation and prolonged survival in a dose-dependent manner. Furthermore, by using a panel of neutralizing anticytokine antibodies, only those antibodies to GM-CSF blocked the effect of Tsn on DC (Table II). Complete blockade of Tsn activity was obtained with $50 \mathrm{NU} / \mathrm{ml} \mathrm{IgG}$ anti-GM-CSF.

Peripheral blood DC cultured for 3-7 d with GM-CSF displayed an array of cell processes (Fig. 2) which tended to protrude and retract repeatedly over time. The adherence of DC to plastic induced by GM-CSF was reversible, inasmuch as the cells frequently detached from the surface of the culture vessel and readhered in a different location. As shown in Fig. 4, the number of differentiated (branched) DC increased as the concentration of GM-CSF in the culture increased. At any given concentration of the cytokine, however, the total number of viable cells as well as the number of branched cells per

Table I. Effect of Various Cytokines on DC Morphology and Viability in Culture

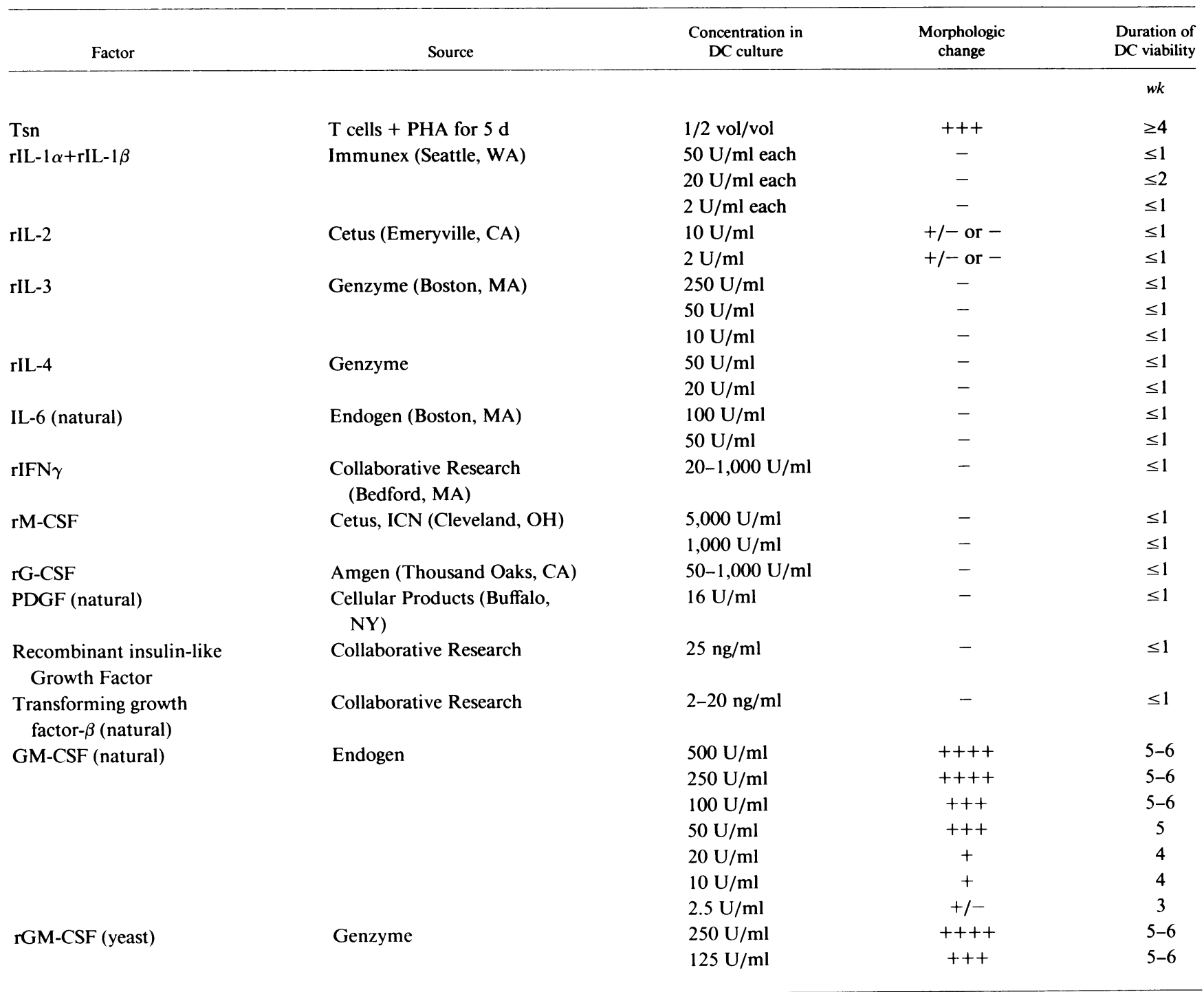

DC were cultured in CM at a concentration of 25,000 cells per well in flat-bottom 96-well tissue culture plates (Costar) in the presence of the indicated agent. DC morphology was determined by phase-contrast microscopy. The number of branching DC per well was scored as follows: - , no differentiated DC; $+/-$, occasional differentiated DC; + , number of branching DC approximately one-third that seen in wells with Tsn; ++ , number of branching DC approximately two-thirds that seen in wells with Tsn; +++ , number of branching DC approximately equal to that seen in wells with Tsn; ++++ , number of branching DC greater than that seen in cultures with Tsn. The results shown represent a summary of 19 separate experiments. 
Table II. Effect of Neutralizing Anti-Cytokine Antibodies on Morphologic Change of CD Induced by Tsn

\begin{tabular}{|c|c|c|c|c|c|}
\hline Experiment & $\begin{array}{c}\text { Reagent } \\
\text { preincubated }\end{array}$ & $\begin{array}{l}\text { Antibody used in } \\
\text { preincubation }\end{array}$ & $\begin{array}{l}\text { Antibody } \\
\text { concentration }\end{array}$ & Antibody source & $\begin{array}{c}\text { DC } \\
\text { differentiation }\end{array}$ \\
\hline \multirow[t]{11}{*}{$1-3$} & Tsn & No antibody & - & - & +++ \\
\hline & Tsn & Preimmune IgG control & $25 \mu \mathrm{g} / \mathrm{ml}$ & Endogen & +++ \\
\hline & Tsn & Anti-TNF $\alpha$ & $250 \mathrm{NU} / \mathrm{ml}$ & Endogen & +++ \\
\hline & Tsn & Anti-IFN $\alpha$ & $1650 \mathrm{NU} / \mathrm{ml}$ & ICN & +++ \\
\hline & Tsn & Anti-IFN $\beta$ & $60 \mathrm{NU} / \mathrm{ml}$ & $\begin{array}{l}\text { Lee Biomolecular } \\
\text { Research Laboratories } \\
\text { (San Diego, CA) }\end{array}$ & +++ \\
\hline & Tsn & Anti-IFN $\gamma$ & $250 \mathrm{NU} / \mathrm{ml}$ & Endogen & +++ \\
\hline & Tsn & Anti-IL-1 & $200 \mathrm{NU} / \mathrm{ml}$ & Endogen & +++ \\
\hline & Tsn & Anti-IL-2 & $86 \mathrm{NU} / \mathrm{ml}$ & Collaborative Research & +++ \\
\hline & Tsn & Anti-lymphotoxin & $250 \mathrm{NU} / \mathrm{ml}$ & Endogen & +++ \\
\hline & Tsn & Anti-GM-CSF & $250 \mathrm{NU} / \mathrm{ml}$ & Endogen & - \\
\hline & Tsn & Anti-IL-6 & $250 \mathrm{NU} / \mathrm{mi}$ & Endogen & +++ \\
\hline \multirow[t]{2}{*}{4,5} & Tsn & No antibody & - & & +++ \\
\hline & Tsn & Preimmune IgG control & $40 \mu \mathrm{g} / \mathrm{ml}$ & Endogen & +++ \\
\hline \multirow[t]{8}{*}{4,5} & Tsn & Anti-GM-CSF & $400 \mathrm{NU} / \dot{\mathrm{ml}}$ & Endogen & - \\
\hline & Tsn & Anti-GM-CSF & $200 \mathrm{NU} / \mathrm{ml}$ & Endogen & - \\
\hline & Tsn & Ainti-GM-CSF & $100 \mathrm{NU} / \mathrm{ml}$ & Endogen & - \\
\hline & Tsn & Anti-GM-CSF & $50 \mathrm{NU} / \mathrm{ml}$ & Endogen & - \\
\hline & Tsn & Anti-GM-CSF & $25 \mathrm{NU} / \mathrm{ml}$ & Endogen & + \\
\hline & Tsn & Anti-GM-CSF & $12.5 \mathrm{NU} / \mathrm{ml}$ & Endogen & ++ \\
\hline & $\begin{array}{l}\text { GM-CSF } \\
\quad(200 \mathrm{U} / \mathrm{ml})\end{array}$ & Anti-GM-CSF & $200 \mathrm{NU} / \mathrm{ml}$ & Endogen & - \\
\hline & $\begin{array}{l}\text { GM-CSF } \\
\quad(200 \mathrm{U} / \mathrm{ml})\end{array}$ & Anti-GM-CSF & $50 \mathrm{NU} / \mathrm{ml}$ & Endogen & +++ \\
\hline
\end{tabular}

DC differentiation was scored as described in the footnote to Table I. Tsn or GM-CSF was preincubated for $5 \mathrm{~h}$ (experiments 1-3) or $2 \mathrm{~h}$ (experiments 4 and 5) with rabbit polyclonal IgG neutralizing antibody, and was then passed through a $0.2-\mu \mathrm{m}$ filter. The concentration of immune-IgG during preincubation is shown in neutralizing units $(\mathrm{NU})$ as provided by manufacturers. DC cultures in CM were supplemented with a half volume of Tsn or GM-CSF solution previously incubated with antibodies. TNF, tumor necrosis factor.

well remained stable over time, suggesting that GM-CSF does not cause DC to divide and proliferate. The possibility that some DC die and are replaced by DC developing from precursor cells present in the initial DC preparation cannot be ruled

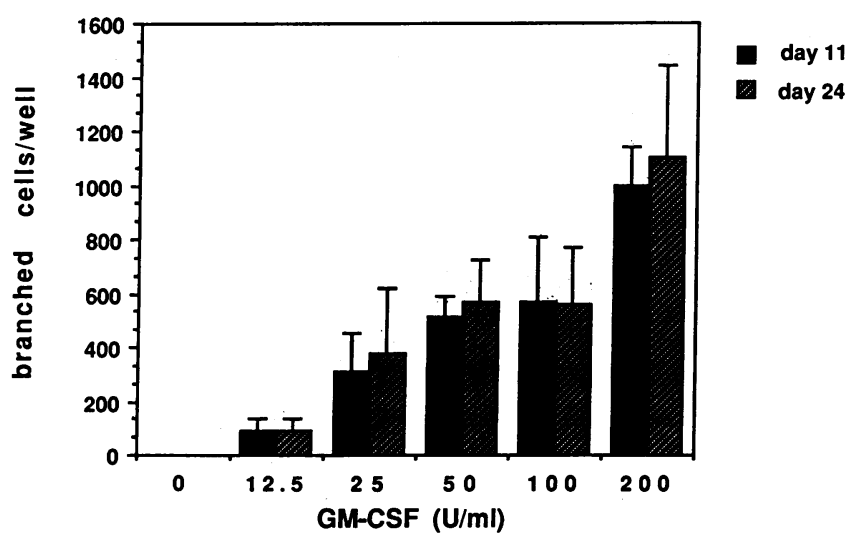

Figure 4. Effect of GM-CSF concentration on number of differentiated (branched) DC. DC were cultured in 96-well flat-bottom plates (Costar) at a density of 20,000 cells per well, and viable, branched DC were identified and counted microscopically. The range of the total number of viable cells per well was $10,000-15,000$ throughout the culture period. out. Indeed, some nonadhering cells were able to adhere and display processes when transferred to another culture vessel (data not shown). Branched DC typically comprised $10-40 \%$ of the total number of viable cells in cultures supplemented with GM-CSF. The remaining cells consisted primarily of unbranched DC (DR+, Leu M3 - cells capable of differentiating into branched adherent cells when transferred), and smaller numbers of macrophages and lymphoid cells.

DC differentiation to branching cells was not dependent on the multistep isolation procedure used for initial enrichment of DC from peripheral blood. If GM-CSF was added directly to cultures of unfractionated peripheral blood mononuclear cells, scattered cells with branching processes regularly appeared within a few days (not shown). Differentiated DC similar to those induced by GM-CSF were occasionally observed in cultures to which recombinant (r)IL-2 had been added. An abundance of rapidly proliferating lymphocytes was also observed in such cultures, attributable to an effect of IL-2 on T cells contaminating the initial DC preparation. We interpret this result as indicating that the effect of IL-2 on DC is most likely an indirect one, mediated by activated $T$ cells producing GMCSF. However, a direct effect of IL-2 on DC is not excluded.

No other cytokine or combination of cytokines tested induced DC differentiation. However, DC remained viable for up to 1 wk in cultures supplemented with IL-1, IL-3, or IL-4, and if GM-CSF or Tsn was added to such cultures, the surviv- 

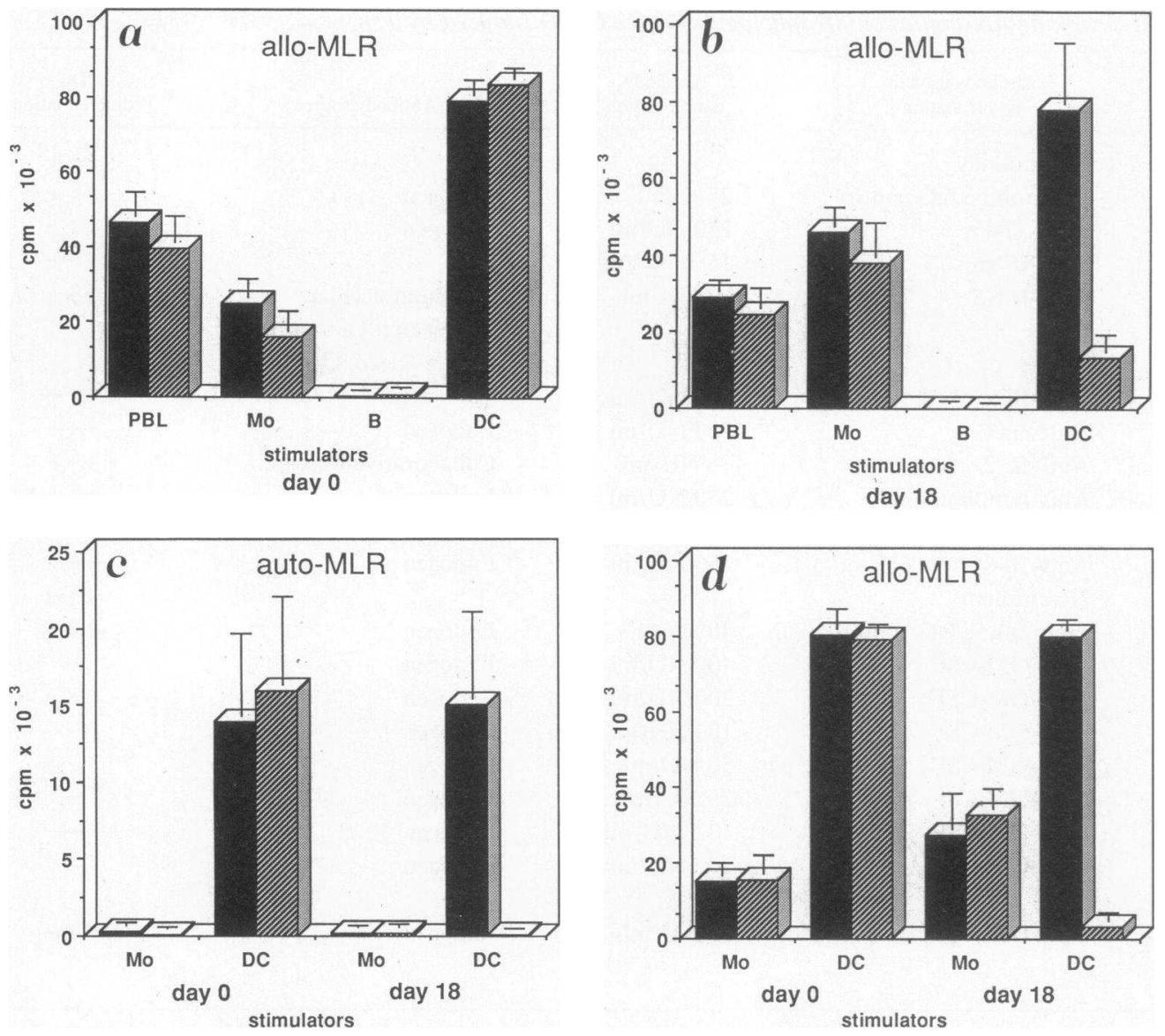

Figure 5. DC cultured in GMCSF maintain their immunostimulatory function in MLR. MLRs were carried out between $5 \times 10^{4} \mathrm{~T}$ cell responders and fresh stimulator populations (day 0 ) or between $T$ responders and stimulator cells which had been cultured for $18 \mathrm{~d}$ with GMCSF (solid bars) or without GMCSF (hatched bars). Day 0 MLRs were also performed in the presence (solid bars) or absence (hatched bars) of GMCSF. (a) Fresh peripheral blood mononuclear cells $(P B L)$, monocytes $(M o)$, B cells $(B)$, and dendritic cells $(D C)$ were cultured with allogeneic T cells. (b) $10 \times$ $10^{3}$ cells of each population were cultured for $18 \mathrm{~d}$ before being used as allogeneic stimulator cells. In a separate experiment, Mo and DC freshly isolated or cultured for $18 \mathrm{~d}$ were used to stimulate $(c)$ autologous $\mathrm{T}$ cells or $(d)$ allogeneic $\mathrm{T}$ cells. In this experiment $20 \times 10^{3}$ autologous and $5 \times 10^{3}$ allogeneic stimulators were used. The incorporation of $\left[{ }^{3} \mathrm{H}\right]$ thymidine by $\mathrm{T}$ cells cultured alone in the presence or absence of exogenous GM-CSF was $<300 \mathrm{cpm}$. ing DC differentiated morphologically and retained their viability for several weeks (data not shown). No enhancement of DC differentiation was observed when IL-1, IL-3, or IL-4 was added simultaneously with GM-CSF at day 0 of culture (data not shown). These results suggest that a variety of interleukins have a relatively short-term impact on DC survival but do not induce DC morphologic differentiation or support their longer-term survival.

The question remained as to whether DC cultured in the presence of Tsn or GM-CSF for prolonged periods retained immune stimulatory activity. In preliminary experiments DC maintained for as long as $30 \mathrm{~d}$ in either Tsn or GM-CSF retained their ability to stimulate allogeneic T cells in the MLR, whereas DC cultured in medium alone lost all stimulatory activity. As shown in Fig. 5, DC but not monocytes/macrophages, require exogenous GM-CSF to maintain their immunostimulatory properties during prolonged culture. Indeed, the residual stimulatory activity of DC-enriched preparations remaining after $18 \mathrm{~d}$ of culture in the absence of exogenous GM-CSF may not be a function of DC since no cells with DC characteristics could be identified in such cultures. Fresh B cells failed to stimulate $T$ cells in allogeneic MLRs and no stimulatory activity in the $\mathrm{B}$ cell fraction was induced during the 18-d culture with GM-CSF. GM-CSF added directly to MLRs between $T$ cells and fresh allogeneic DC or fresh allogeneic macrophages had no effect on $\mathrm{T}$ cell proliferation (Fig. 5, $a$ and $d$ ).
DC cultured in the presence of GM-CSF for $18 \mathrm{~d}$ also retained the ability to stimulate the proliferation of autologous $\mathrm{T}$ cells in autologous MLRs (Fig. $5 c$ ). In contrast, despite their ability to stimulate allogeneic T cells (Fig. $5 d$ ), neither fresh macrophages nor macrophages cultured in the presence or absence of GM-CSF had any stimulatory effect on autologous $\mathrm{T}$ cells.

As a general rule, DC isolated from a variety of tissues do not require exogenous cytokines to provide accessory cell/immune stimulatory function for $\mathrm{T}$ cells (reviewed in Steinman [15]). Mouse epidermal Langerhans cells, a type of DC, represent an exception to this rule. Despite their rich expression of class II MHC determinants, such cells fail to stimulate allogeneic $T$ cells unless they are first exposed to $\operatorname{GM}-\operatorname{CSF}(16,17)$. After 1-3 d culture in GM-CSF, the accessory activity of Langerhans cells increases 10-30-fold, equaling the potent activity of splenic DC. IL-1 enhances the effect of GM-CSF but has no independent role in the maturation of Langerhans cells (16, 17). The effects of GM-CSF on human peripheral blood DC observed here-induction of morphologic changes as well as long-term viability - are clearly distinct from the pattern described for mouse epidermal Langerhans cells. More importantly, these findings indicate that GM-CSF can directly regulate the activity of functionally competent dendritic accessory cells. Since this cytokine is produced by a variety of cell types, including immunologically stimulated $\mathrm{T}$ cells, macrophages and endothelial cells $(10,11,18)$, any or all of these cell popu- 
lations can potentially be involved in the regulation of peripheral blood DC in vivo. In addition, it is possible that the effect of GM-CSF, on DC contributes to the clinical benefits observed in the initial therapeutic trials of recombinant GM-CSF in patients with cancer (19) and AIDS (20).

\section{Acknowledgments}

The authors wish to thank Claudia Benike for helpful discussions.

This work was supported in part by grants CA24607, AI25922, and AI72657 from the National Institutes of Health.

\section{References}

1. Steinman, R. M., and M. C. Nussenzweig. 1980. Dendritic cells: features and functions. Immunol. Rev. 53:127-147.

2. Van Vorhis, W. C., L. S. Hair, R. M. Steinman, and G. Kaplan. 1982. Human dendritic cells: enrichment and characterization from peripheral blood. J. Exp. Med. 155:1172-1187.

3. Zvaifler, N. J., R. M. Steinman, G. Kaplan, L. L. Lau, M., and M. Rivelis. 1985. Identification of immunostimulatory dendritic cells in the synovial effusions of patients with rheumatoid arthritis. J. Clin. Invest. 76:789-800.

4. Young, J. W., and R. M. Steinman. 1988. Accessory cell requirements for the mixed leukocyte reaction and polyclonal mitogens, as studied with a new technique for enriching blood dendritic cells. Cell. Immunol. 111:167-182.

5. Inaba, K., and R. M. Steinman. 1985. Protein-specific helper T-lymphocyte formation initiated by dendritic cells. Science (Wash. DC). 229:475-479.

6. Hauser, C., and S. I. Katz. 1988. Activation and expansion of hapten- and protein-specific $\mathrm{T}$ helper cells from nonsensitized mice. Proc. Natl. Acad. Sci. USA. 85:5625-5628.

7. Macatonia, S. E., P. M. Taylor, S. C. Knight, and B. A. Askonas. 1989. Primary stimulation by dendritic cells induces antiviral proliferative and cytotoxic T cell responses in vitro. J. Exp. Med. 169:12551264.

8. Patterson, S., and S. C. Knight. 1987. Susceptibility of human peripheral blood dendritic cells to infection by human immunodeficiency virus. J. Gen. Virol. 68:1177-1181.
9. Tschlachler, E., V. Groh, M. Popovic, D. L. Mann, K. Konrad, B. Safai, L. Eron, F. di Marzo Veronese, K. Wolff, and G. Stingl. 1987. Epidermal Langerhans cells-a target for HTLV-III/LAV infection. $J$. Invest. Dermatol. 88:233-237.

10. Sieff, C. A. 1987. Hematopoietic growth factors. J. Clin Invest. 79:1549-1557.

11. Clark, S. C., and R. Kamen. 1987. The human hematopoietic colony-stimulating factors. Science (Wash. DC). 236:1229-1237.

12. Böyum, A. 1968. A one-stage procedure for isolation of granulocytes and lymphocytes from human blood. Scand. J. Clin. Lab. Invest. 21:21-29.

13. Wybran, J., S. Chantler, and H. H. Fudenberg. 1973. Isolation of normal T cells in chronic lymphocytic leukaemia. Lancet. $i: 126-$ 129.

14. Engleman, E. G., C. J. Benike, F. C. Grumet, and R. L. Evans. 1981. Activation of human T lymphocyte subsets: helper and suppressor/cytotoxic cells recognize and respond to distinct histocompatibility antigens. J. Immunol. 127:2124-2129.

15. Steinman, R. M. 1988. Cytokines amplify the function of accessory cells. Immunol. Lett. 17:197-202.

16. Witmer-Pack, M. D., W. Olivier, J. Valinsky, G. Schuler, and R. M. Steinman. 1987. Granulocyte/macrophage colony-stimulating factor is essential for the viability and function of cultured murine epidermal Langerhans cells. J. Exp. Med. 166:1484-1498.

17. Heufler, C., F. Koch, and G. Schuler. 1988. Granulocyte/macrophage colony-stimulating factor and interleukin 1 mediate the maturation of murine epidermal Langerhans cells into potent immunostimulatory dendritic cells. J. Exp. Med. 167:700-705.

18. Sieff, C. A., S. Tsai, and D. V. Faller. 1987. Interleukin 1 induces cultured human endothelial cell production of granulocytemacrophage colony stimulating factor. J. Clin. Invest. 79:48-51.

19. Brandt, S. J., W. P. Peters, S. K. Atwater, J. Kurtzberg, M. J. Borowitz, R. B. Jones, E. J. Shpall, R. C. Bast, Jr., C. J. Gilbert, and D. J. Dette. 1988. Effect of recombinant human granulocyte-macrophage colony-stimulating factor on hematopoietic reconstitution after high-dose chemotherapy and autologous bone marrow transplantation. N. Engl. J. Med. 318:869-876.

20. Groopman, J. E., R. T. Mitsuyasu, M. J. De Leo, D. H. Ocite, and D. W. Golde. 1987. Effect of recombinant human granulocytemacrophage colony-stimulating factor on myelopoiesis in the acquired immunodeficiency syndrome. N. Engl. J. Med. 317:593-626. 